\title{
Kernos
}

Revue internationale et pluridisciplinaire de religion grecque antique

18 | 2005

Varia

\section{Ilias N. ARNAOUTOGLOU, Thusias heneka kai sunousias. Private religious associations in Hellenistic Athens}

\section{Yulia Ustinova}

\section{(2) OpenEdition \\ Journals}

Electronic version

URL: http://journals.openedition.org/kernos/1722

DOI: 10.4000/kernos.1722

ISSN: 2034-7871

\section{Publisher}

Centre international d'étude de la religion grecque antique

\section{Printed version}

Date of publication: 1 January 2005

Number of pages: $542-545$

ISSN: 0776-3824

\section{Electronic reference}

Yulia Ustinova, « Ilias N. ARnaoutoglou, Thusias heneka kai sunousias. Private religious associations in Hellenistic Athens », Kernos [Online], 18| 2005, Online since 24 May 2011, connection on 21

September 2020. URL : http://journals.openedition.org/kernos/1722 ; DOI : https://doi.org/10.4000/ kernos. 1722 
régimes aristocratiques, l'A. propose de voir un parallèle métaphorique (p. 322-323) entre la santé des hommes et celle d'une constitution comme en témoignerait, selon

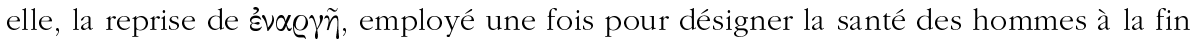
du péan (1. 55-56), l'autre fois pour qualifier les paroles du dieu annonçant sa décision d'aller au secours de Sparte et de sa constitution (1. 67). Si le caractère politique de la fonction dévolue alors à la divinité ne fait pas de doute, sans doute conviendrait-il, pour mieux l'expliquer, de ne pas partir de l'idée a priori qu'Asklépios est « un dieu apparemment si étranger à la cité » mais, au contraire, de s'interroger d'emblée sur les relations que ce dernier entretient, à Épidaure comme ailleurs (et notamment à Messène), avec les communautés civiques.

L'ouvrage comprend en annexe un choix de treize lois sacrées (textes et traductions) correspondant à celles qui ont été utilisées pour établir la comparaison avec celle qui est formulée dans l'inscription d'Isyllos, ainsi que les textes relatifs à la naissance d'Asklépios. S'y ajoute un long appendice de plus d'une trentaine de pages intitulé « $\sum \omega \tau$ iń : Démétrios Poliorcète, Ptolémée Ier et Asclépios »; l'A. cherche à établir un « rapprochement » entre l'Asklépios d'Isyllos et les souverains hellénistiques en question, à qui l'épithète a été attribué. La question a été posée dans le cours du dernier chapitre (p. 326) et l'on voit mal pourquoi son traitement est alors rejeté hors du texte principal. On trouve alors un certain nombre de considérations sur le culte rendu aux souverains hellénistiques, le texte, traduit et commenté, de l'hymne des Athéniens en l'honneur de Démétrios Poliorcète ainsi que le passage de l'inscription se rapportant à l'épiphanie d'Athéna Lindia qui aurait conduit à l'intervention de Ptolémée I ${ }^{\text {er }}$ à la fin du siège de Rhodes par Démétrios. Des points communs sont alors recherchés, en particulier entre les modalités de l'intervention du dieu dans l'inscription d'Isyllos et celles de l'action des souverains, ce qui permet d'aboutir à la conclusion que le texte d'Isyllos reprend certains éléments constitutifs de la propagande utilisée par les souverains hellénistiques. Une bibliographie et des indices complètent cet ouvrage.

En dépit de pages parfois moins convaincantes et qui, à tout le moins, ouvrent le champ de la discussion, l'ensemble constitue d'ores et déjà l'ouvrage de référence sur l'inscription d'Isyllos d'Épidaure tout en brossant un portrait d'Asclépios en " habit de citoyen », au cour des relations entre religion et politique, une place que les études antérieures avaient souvent ignorée.

Pierre Sineux

(Université de Caen)

Ilias N. ARnaoutoglou, Thusias heneka kai sunousias. Private religious associations in Hellenistic Athens, Athens, Academy of Athens, 2003. 1 vol. $17 \times 24$ cm, 231 p. (Academy of Athens. Yearbook of the Research Centre for the History of Greek Law, 37, supplement 4). ISBN : 960-404-034-0.

The title of this book comprises two phrases, one in ancient Greek, the other one in modern English. This dichotomy reflects a basic characteristic of the subject: it can be adequately described and perceived only within the framework of the Greek culture, whereas modern definitions and comparisons, indispensable its discussion, are always inaccurate, and often misleading. The author (henceforth A.) is completely aware of this problem. The book starts with a warning that modern word usage and ideas about cult groups in the contemporary world are inappropriate for Classical and Hellenistic Athens. Towards the end of his study, the A. demonstrates that "the modern 
legal background of associations ... is entirely irrelevant to the Athenian experience" (p. 119)

He is less explicit about the applicability of another present-day notion, the opposition of private to public, to the discussion of Athenian associations. The word 'private' appears in the title, although on several occasions the A. emphasizes the mutual permeability of various spheres of activity of the Athenian democracy and Athenian associations (e.g. pp. 21, 156). During the last decade, the study of 'private' vs. 'public' in the life of ancient Greeks attracts a growing number of researchers, as a number of recent conferences on this theme indicate: for instance, the colloquium "Entre public et privé en Grèce ancienne: lieux, objets, pratiques," organized by Centre Louis-Gernet in 1995 (Ktèma 23 [1998]) and the conference of CIERGA "Idia kai demosia. Les cadres 'privés' et 'publics' de la religion grecque antique", held in the University of Fribourg (Switzerland) in 2003 (Kernos, suppl. 15 [2005]). It becomes increasingly clear that the spheres of 'private' and 'public' in Greek cult practices and social life were intermingled to such an extent that even the use of the terms seems problematic. In particular, the demarcation line between private and public associations in the Greek polis was blurred. It would therefore be more accurate to tag Greek associations as 'voluntary,' rather than 'private,' as the A. does.

The book is based on the A.'s Ph.D. study of forms and legal features of religious association in Athens, carried out at Glasgow University under the supervision of D.M. MacDowell. The main text of the book is followed by two appendixes: a catalogue of epigraphic testimonia (p. 171-186) and a list of known members of Athenian associations (187-206).

The Introduction (p. 19-30) gives a brief summary of the research on Greek associations during the last two centuries, and a condensed exposition of the A.'s methodology. In the A.'s view, "cult association is nothing more than a Weberian ideal type, useful in pinpointing the divergence of societal organizational models" (p. 27). Real associations were different from place to place and from period to period, which means that they are to be studied within their historical context, and that extreme caution is required in reconstructions based on parallels. Another essential observation concerns the limitations of the existing record: although the bulk of epigraphic material is dated to the $4^{\text {th }}$ cent. BC and later, private cult associations undoubtedly came into existence earlier, and remained unattested, because the 'epigraphic habit' spread only in the early Hellenistic era. These and other principles define the A.'s approach to the evidence, both epigraphic and literary, in the following chapters.

Chapter 1, "Pieces of Evidence" (p. 31-88), is a discussion of the available evidence on the activities of cult associations identified in their documents as orgeones, thiasotai, and eranistai. Special attention is paid to the terminological difference between epigraphic and literary dossiers, as well as to the chronology, hence to the historical context of the information. Although certain positions may be questioned, as for instance the A.'s reluctance to commit himself to an opinion on the origin of the law ascribed to Solon in the Digest (47. 22. 4), the diachronic analysis of the record enables the A. to come to important conclusions on the nature of various groups. He shows that "... orgeones denote invariably portions of the population connected either by social qualification $\ldots$ or $\ldots$ by religious identities and through them with local identities. Indeed, the latter is the only element that associates the late sources with the earlier and gives us a coherent picture of a possible evolution and continuity" (p. 57) As to thiasotai, the A. argues that in the literary tradition the range of possible meanings attributed to the words thiasos and thiasotai "indicate that these words may 
describe different patterns of communal living, whose common feature was conviviality" (p. 64). The A. puts forward a subtle distinction between thiasos and thiasotai in the epigraphic evidence: "... the word thiasos is used either as a subdivision of the phratry, ... or to indicate a religious function of any group of thiasotai in which nonthiasotai could take part. The term thiasotai is used in general to describe not only the members of a phratry's thiasos, but also to define a private cult association, acquiring in this way a broader sense" (p. 70). This assumption remains not entirely convincing, given the wide spectrum of meanings of the words thiasos and thiasotai. In contrast, the need of discrimination between the words eranos and eranistai is more persuasive. The A. demonstrates that before the first century the term eranos means 'loan' and has nothing to do with associations, whereas the terms eranistai and koinon eraniston designate members of an association or an association, possibly, but not necessarily, involved in financial affairs.

Chapter 2, "The Structure of the Groups" (p. 89-118), deals with the administration of the associations, their membership, assembles, and offices, as well as honours bestowed on eminent members. While stressing certain features of the associations that have already been established by his predecessors, such as the emulation of the polis administration, the A. provides some stimulating insights concerning the organization of private associations. The lack of provisions concerning their dissolution, as opposed to minute stipulations for apparently less crucial events, has puzzled many scholars. The A. gives a very reasonable explanation for this neglect: cult groups had a religious dimension, which meant that "dissolving a group devoted to the cult could mean dishonouring the god or the goddess" (p. 95) and might ensue his or her wreath. The continuation of the group's activities was considered guaranteed through the introduction of new members, be they children or strangers. A keen analysis of decrees of private cult associations discloses their real and proclaimed values and aspirations.

Most interesting are the two closing chapters of the book. Chapter 3, "Looking for the Rules..." (p. 119-144), is devoted to the legal basis of associations. The A. demonstrates the irrelevance of the approach based on application of present-day notions, such as juristic personality, to the analysis of the Athenian experience. Instead, he follows Aristotle's statement that associations were a part of the polis, and envisages their functioning in the framework of the Athenian polis. Here, as in other chapters, the A. grounds his assumptions on thorough analysis of the evidence, and especially of the particularities of word usage in the documents of associations. His observations on the meaning of the words nomos and psephisma in these documents, on the significance of the terms designating associations, and on the peripheral nature of property matters for the assessment of the juristic personality of Athenian associations are very convincing. As a result, the A. defines cult associations as "structured collective entities" (p. 142), and emphasizes their role as "centers of civic activity, in which established beliefs were reassured and socially expected attitudes were rewarded" (p. 143). In the case of non-citizens, the associations both delimited their particularity and "reproduced civic virtues and attitudes"(p. 143), which created an atmosphere of tolerance towards them, and their integration in the long run.

Finally, Chapter 4, "Cult Associations on the Ground" (p. 145-164), examines the experience of Athenian associations after the fourth century, when the polis lost its independence, and was governed by notables rather than by the people's assembly. The A. demonstrates that associative life involved several features of the model of "euergetism," which reflect their integration into the social context of their time. However, other characteristics, as for instance "the forging power of the group's 
identity and cohesion" (p. 153), which cannot be incorporated into this model, find their explanation in the integrative function of the associations. Associations differed in another important respect: their membership ranged from exclusively citizen to foreign. Nevertheless, according to the A., it would be misleading to label even the latter as marginal, since they followed the mainstream system of values. The A. prudently avoids attributing uniform attitudes and modes of existence to all the Athenian associations, which were in his view "multi-functional units of people," pursuing different aims and acting in various ways inside the wider society.

The research on associations in the Greek world seems to surge every half a century: E. Ziebarth (Das griechische Vereinswesen, Leipzig, 1896) and F. Poland (Geschichte des griechischen Vereinswesens, Leipzig, 1909) on the turn of the $20^{\text {th }}$ century, were followed by W.S. Ferguson ("The Attic Orgeones", HThR 37 [1944], p. 61-140 and other works) in the middle of the century, and by N.F. Jones (The Associations of Classical Athens, New York, 1999) and I. A. Arnaoutoglou five decades later. The book by Ilias N. Arnaotoglou is a valuable contribution to this research. The A. combines precise analysis of testimonia with measured application of sociological theory, as well as profound understanding of the changing historical context and its effect on the associations. The resulting diachronic study succeeds in establishing the place of cult associations in the social framework of the Athenian polis.

Yulia Ustinova

(Ben-Gurion University of the Negev)

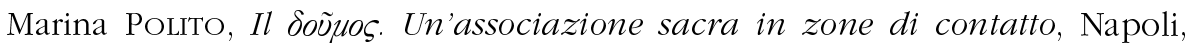
Università degli studi di Salerno, Dipartimento di Scienze dell'Antichità, 2004. 1 vol. $17 \times 23,5 \mathrm{~cm}, 114$ p. ISBN : 88-87375-74-7.

Le mot rare $\delta$ õuos, signifiant «confrérie » et sans doute aussi «lieu de rassemblement », est attesté en grec depuis le vi siècle av. J.-C. et dérive d'une langue de l'Asie Mineure occidentale qu'il est impossible d'identifier avec certitude (lydien, méonien ou phrygien). Ceci a pu être établi à partir de l'apparition de ce terme dans des inscriptions d'époque impériale provenant de Lydie (précisément de Méonie), publiées pour la première fois par Karl Buresch il y a plus d'un siècle'. En 1987, Olivier Masson dédia à ce mot une étude très fouillée $e^{2}$ Quelques années plus tard une inscription funéraire trouvée à Thessalonique est venue s'ajouter au dossier. Dans ce petit volume, l'A. dresse un bilan de la recherche et propose une synthèse à partir des données disponibles. L'ouvrage comprend (1) une introduction, (2) un aperçu du problème linguistique et des solutions proposées (étymologie et sens originel du mot), (3) un catalogue de toutes les attestations de doumos, épigraphiques d'abord et littéraires ensuite, avec textes et commentaires, (4) une discussion de ce type d'association sous tous ses aspects et (5) un résumé des principales conclusions; il se termine par une longue bibliographie et une carte indiquant la distribution géographique des doumo $i$ attestés.

Une première remarque concerne la potrée de cette étude. Selon l'A. son objectif est de présenter une «vue d'ensemble» du doumos, qu'elle considère d'emblée

\footnotetext{
1 K. Buresch, Aus Lydien, Leipzig 1898, p. 60-61.

O. MASSOn, «Le mot doumos, 'confrérie', dans les textes et les inscriptions », Cabiers Ferdinand de Saussure 41 (1987), p. 145-152

3 E. VOUTIRAS, «Berufs- und Kultverein: ein doumos in Thessaloniki », ZPE 90 (1992), p. 8796.
} 